\title{
Front Matter: Volume 6951
}

, "Front Matter: Volume 6951," Proc. SPIE 6951, Atmospheric Propagation V, 695101 (13 May 2008); doi: 10.1117/12.801209

SDIE Event: SPIE Defense and Security Symposium, 2008, Orlando, Florida, SPIE. United States 


\section{PROCEEDINGS OF SPIE}

\section{Atmospheric Propagation V}

G. Charmaine Gilbreath Linda M. Wasiczko

Editors

18-20 March 2008

Orlando, Florida, USA

Sponsored and Published by

SPIE

Volume 6951

Proceedings of SPIE, 0277-786X, v. 6951 
The papers included in this volume were part of the technical conference cited on the cover and title page. Papers were selected and subject to review by the editors and conference program committee. Some conference presentations may not be available for publication. The papers published in these proceedings reflect the work and thoughts of the authors and are published herein as submitted. The publisher is not responsible for the validity of the information or for any outcomes resulting from reliance thereon.

Please use the following format to cite material from this book:

Author(s), "Title of Paper," in Atmospheric Propagation V, edited by G. Charmaine Gillbreath, Linda M. Wasiczko, Proceedings of SPIE Vol. 6951 (SPIE, Bellingham, WA, 2008) Article CID Number.

ISSN 0277-786X

ISBN 9780819471420

Published by

SPIE

P.O. Box 10, Bellingham, Washington 98227-0010 USA

Telephone +1 3606763290 (Pacific Time) · Fax +1 3606471445

SPIE.org

Copyright (C 2008, Society of Photo-Optical Instrumentation Engineers

Copying of material in this book for internal or personal use, or for the internal or personal use of specific clients, beyond the fair use provisions granted by the U.S. Copyright Law is authorized by SPIE subject to payment of copying fees. The Transactional Reporting Service base fee for this volume is $\$ 18.00$ per article (or portion thereof), which should be paid directly to the Copyright Clearance Center (CCC), 222 Rosewood Drive, Danvers, MA 01923. Payment may also be made electronically through CCC Online at copyright.com. Other copying for republication, resale, advertising or promotion, or any form of systematic or multiple reproduction of any material in this book is prohibited except with permission in writing from the publisher. The CCC fee code is $0277-786 \mathrm{X} / 08 / \$ 18.00$.

Printed in the United States of America.

Publication of record for individual papers is online in the SPIE Digital Library.

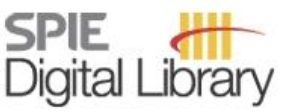

SPIEDigitallibrary.org

Paper Numbering: Proceedings of SPIE follow an e-First publication model, with papers published first online and then in print and on CD-ROM. Papers are published as they are submitted and meet publication criteria. A unique, consistent, permanent citation identifier (CID) number is assigned to each article at the time of the first publication. Utilization of CIDs allows articles to be fully citable as soon they are published online, and connects the same identifier to all online, print, and electronic versions of the publication. SPIE uses a six-digit CID article numbering system in which:

- The first four digits correspond to the SPIE volume number.

- The last two digits indicate publication order within the volume using a Base 36 numbering system employing both numerals and letters. These two-number sets start with 00, 01, 02, 03, 04, 05, $06,07,08,09,0 A, 0 B \ldots 0 Z$, followed by $10-12,20-2 Z$, etc.

The CID number appears on each page of the manuscript. The complete citation is used on the first page, and an abbreviated version on subsequent pages. Numbers in the index correspond to the last two digits of the six-digit CID number. 


\title{
Contents
}

\author{
vii Conference Committee \\ ix Introduction
}

\section{SESSION 1 THEORETICAL STUDIES}

695102 FSO communications: atmospheric effects for an airborne backbone (Invited Paper) [6951-01]

R. L. Phillips, L. C. Andrews, Univ. of Central Florida (USA)

695103 The spatial-temporal evolution of the far field irradiance distribution from a Gaussian beam due to atmospheric turbulence in the boundary layer [6951-02]

R. Oermann, Univ. of Adelaide (Australia)

695104 Turbulent thermal blooming [6951-03]

K. Petrowski, D. Limsui, C. Menyuk, R. Joseph, M. Thomas, W. Torruellas, Johns Hopkins Univ. (USA)

695105 Branch point detection and correction using the branch point potential method [6951-04] K. Murphy, R. Mackey, C. Dainty, National Univ. of Ireland, Galway (Ireland)

695106 Simulated impact of aero-optical effects on a 200 km air-to-air lasercomm link [6951-05] K. R. Bock, G. J. Baker, Lockheed Martin Advanced Technology Ctr. (USA)

695108 Mirage effects in the marine layer across Chesapeake Bay [6951-33]

C. O. Font, U.S. Naval Research Lab. (USA); C. A. Armstrong, Norfolk State Univ. (USA);

G. C. Gilbreath, L. Parchment, M. Suite, H. R. Burris, U.S. Naval Research Lab. (USA)

695109 Testing of LIDAR system for turbulence profiles [6951-32]

G. G. Gimmestad, D. W. Roberts, J. M. Stewart, J. W. Wood, Georgia Institute of Technology (USA); F. D. Eaton, Air Force Research Lab. (USA)

\section{SESSION 2 THEORY AND EXPERIMENT I}

6951 OA Channel capacity limits for free-space optical links (Invited Paper) [6951-07]

D. M. Boroson, MIT Lincoln Lab. (USA)

6951 OE Algorithm for haze determination using digital camera images [6951-11]

C. J. Wong, M. Z. MatJafri, K. Abdullah, H. S. Lim, S. A. Hashim, Univ. Sains Malaysia (Malaysia) 
6951 OG Propagation variability assessments of ship defense HEL and HPM performance in worldwide maritime boundary layer environments at wavelengths of $1.0642 \mu \mathrm{m}, 2.141 \mu \mathrm{m}$, $3.16 \mathrm{~mm}$ and $12.2 \mathrm{~cm}[6951-14]$

S. T. Fiorino, R. J. Bartell, M. J. Krizo, S. J. Cusumano, Air Force Institute of Technology (USA)

$6951 \mathrm{OH}$ Real-time scintillation noise mitigation for free space optical transmission of analogue and digital signals [6951-15]

K. J. Grant, B. A. Clare, K. A. Mudge, B. M. Sprey, R. J. Oermann, Defence Science and Technology Organisation (Australia)

6951 0l Development of the polarization tracking scheme for free-space quantum cryptography [6951-16]

M. Toyoshima, Y. Takayama, H. Kunimori, M. Takeoka, M. Fujiwara, M. Sasaki, National Institute of Information and Communications Technology (Japan)

\section{SESSION 4 EXPERIMENTAL STUDIES I}

6951 OL A tabletop turbulence generator [6951-19]

D. Soreide, Optimal Aerospace (USA); J. Saint Clair, P. Cassaday, The Boeing Co. (USA)

6951 ON Maximizing receiver misalignment tolerance in a hybrid wireless system [6951-21]

P. G. LoPresti, C. Kiister, S. Spaunhorst, Univ. of Tulsa (USA); H. Refai, Univ. of Oklahoma (USA)

\section{SESSION 5 EXPERIMENTAL STUDIES II}

6951 OP Measurement of optical refraction across the Chesapeake Bay (Invited Paper) [6951-25] W. P. Hooper, Naval Research Lab. (USA)

$6951 \mathrm{OQ}$ A comparative study of $3.6 \mu \mathrm{m}$ and $1.55 \mu \mathrm{m}$ atmospheric transmission [6951-23] R. Mahon, L-3 Communications Inc. (USA); H. R. Burris, M. S. Ferraro, C. I. Moore, W. S. Rabinovich, M. R. Suite, W. W. Bewley, C. L. Canedy, D. Larrabee, J. R. Meyer, I. Vurgaftman, Naval Research Lab. (USA)

6951 OS NRL's research at the Lasercomm Test Facility: characterization of the maritime atmosphere and initial results in analog FM lasercomm [6951-26]

L. M. Wasiczko Thomas, C. I. Moore, H. R. Burris, M. Suite, W. R. Smith, Jr., W. Rabinovich, US Naval Research Lab. (USA)

\section{SESSION 6 EXPERIMENTAL STUDIES III}

6951 OT Atmospheric propagation of novel MWIR laser output for emerging free-space applications (Invited Paper) [6951-22]

A. M. Tabirian, D. P. Stanley, D. E. Roberts, A. B. Thompson, Northrop Grumman Laser Systems (USA) 
6951 OU Results from long term studies of packet testing at the U.S. Naval Research Laboratory freespace lasercomm test facility [6951-27]

M. R. Suite, H. R. Burris, C. I. Moore, L. M. Wasiczko, Naval Research Lab. (USA); R. Mahon, L-3 Communications (USA); W. S. Rabinovich, Naval Research Lab. (USA)

6951 OV High speed lasercomm data transfer in Seahawk 2007 exercise [6951-28]

H. R. Burris, C. I. Moore, J. R. Waterman, M. R. Suite, Naval Research Lab. (USA);

K. Vilardebo, V Systems, Inc. (USA); L. M. Wasiczko, W. S. Rabinovich, Naval Research Lab. (USA); R. Mahon, L-3 Communications (USA); M. S. Ferraro, Naval Research Lab. (USA); E. Sainte Georges, S. Uecke, NovaSol (USA); P. Poirier, M. Lovern, F. Hanson, SPAWAR Systems Ctr., San Diego (USA)

\section{SESSION 7 FREESPACE LASERCOMM SYSTEMS}

6951 OW Free space optical communications: coming of age (Keynote Paper) [6951-30] L. B. Stotts, Defense Advanced Research Projects Agency (USA); B. Stadler, Air Force Research Lab. (USA); G. Lee, Lutronix (USA)

Author Index 
Downloaded From: https://www.spiedigitallibrary.org/conference-proceedings-of-spie on 26 Apr 2023

Terms of Use: https://www.spiedigitallibrary.org/terms-of-use 


\title{
Conference Committee
}

\author{
Symposium Chair
}

Larry B. Stotts, Defense Advanced Research Projects Agency (USA)

Symposium Cochair

Ray O. Johnson, Lockheed Martin Corporation (USA)

Program Track Chair

Gary W. Kamerman, FastMetrix, Inc. (USA)

Conference Chairs

G. Charmaine Gilbreath, Naval Research Laboratory (USA)

Linda M. Wasiczko, Naval Research Laboratory (USA)

Program Committee

Larry C. Andrews, University of Central Florida (USA)

Gary J. Baker, Lockheed Martin Advanced Technology Center (USA)

Harris R. Burris, Naval Research Laboratory (USA)

Frank D. Eaton, Air Force Research Laboratory (USA)

Gary G. Gimmestad, Georgia Tech Research Institute (USA)

Kenneth J. Grant, Defence Science and Technology Organisation (Australia)

Chadwick T. Hawley, Signatures Program Management Office (USA)

Norman S. Kopeika, Ben-Gurion University of the Negev (Israel)

Martin Kruger, Office of Naval Research (USA)

Christopher I. Moore, Naval Research Laboratory (USA)

Sergio R. Restaino, Naval Research Laboratory (USA)

Jennifer C. Ricklin, Defense Advanced Research Projects Agency

(USA)

Jonathan M. Saint Clair, The Boeing Company (USA)

Ove K. Steinvall, Swedish Defence Research Agency (Sweden)

Cynthia Y. Young, University of Central Florida (USA)

Session Chairs

1 Theoretical Studies

Jonathan M. Saint Clair, The Boeing Company (USA) 
2 Theory and Experiment I

Harris R. Burris, Naval Research Laboratory (USA)

3 Theory and Experiment II

Frida E. Vetelino, Aerospace Missions Corporation (USA)

4 Experimental Studies I

Kevin R. Bock, Lockheed Martin Advanced Technology Center (USA)

5 Experimental Studies II

Gary G. Gimmestad, Georgia Tech Research Institute (USA)

6 Experimental Studies III

Linda M. Wasiczko, Naval Research Laboratory (USA)

7 Freespace Lasercomm Systems

G. Charmaine Gilbreath, Naval Research Laboratory (USA)

Panel Discussion on Freespace Lasercomm

Larry B. Stotts, Defense Advanced Research Projects Agency (USA)

Don. M. Boroson, MIT Lincoln Laboratory (USA)

Ronald L. Phillips, University of Central Florida (USA)

Larry C. Andrews, University of Central Florida (USA)

Morio Toyoshima, National Institute of Information and

Communications Technology (Japan)

Monte Ross, FastMetrix, Inc. (USA) 


\section{Introduction}

This year's conference on Atmospheric Propagation was intellectually rich as well as broad in its coverage of how transmission visible and infrared light is affected by the atmosphere. As in previous conferences, theoretical and analytical approaches as well as experimental results were presented.

This year, however, there was a subtext to the papers culminating in a panel discussion on the second day on the readiness of freespace optical communications for use in the larger sectors.

This theme is embodied in DARPA's ORCA program to be lead by Dr. Larry Stotts. Dr. Stotts lead the panel discussion with a keynote address where he reviewed the history of attempts to transition laser communications technology into the commercial and DOD sectors. His question to all of us was, "Are we still an 'emerging capability' after over thirty years?" He ended his keynote with a description of ORCA for which he is the program manager. Dr. Stotts's strong feelings regarding the readiness of Lasercom were made known and became a focus point for discussion.

Panelists varied from "bullish" to more cautious. Most, however, felt that first generation laser communications is ready for transition. Dr. Phillips encouraged tenacity and called to the DOD to remain an important underwriter and agent to effect transition. Dr. Andrews agreed and reminded all that we are still faced with the challenges of the physics of the atmosphere but they are solvable. Don Boroson was "bullish" (his words) and charged the community to beware of bad engineering - that we must pay the true cost to "do it right." Monte Ross gave some early history and concurred that there is still a need for the government to commit long-term investments in sources, detectors, and systems. Morio Toyoshima offered Japan's viewpoint. In his country where space-based and terrestrial lasercom have been successfully demonstrated, the main question is, "Who is the user?" These comments all prompted Larry Stotts to call for an effective strategy. Comments and questions from the floor were then accepted and the discussion remained lively to the end of the conference day.

The conference chairs would like to take this opportunity to expressly thank all of the authors who contributed this year and to several who presented late additions to fill time periods left by canceled papers. These additional authors are: Dr. Larry Andrews and Dr. Ron Phillips, Dr. John Degnan, Mr. Carlos Font, and Dr. H. Ray Burris. Thanks also to Dr. Morio Toyoshima and Dr. Monte Ross for their participation on our panel at the end of the day.

\section{G. Charmaine Gilbreath Linda M. Wasiczko}


Downloaded From: https://www.spiedigitallibrary.org/conference-proceedings-of-spie on 26 Apr 2023

Terms of Use: https://www.spiedigitallibrary.org/terms-of-use 